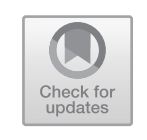

\title{
A Man's Sphere? British Politics in the Eighteenth and Nineteenth Centuries
}

\author{
Matthew McCormack
}

The study of masculinity is now well established within the discipline of history, but its impact has been uneven. As the essays in this collection show, historians of different periods, regions and topics have often explored it in quite distinctive ways. The study of masculinity in British politics is a case in point. This is a national context where gender clearly plays a huge role in political culture, but the particular ways in which the histories of gender and politics have developed in Britain has meant that a dedicated history of political masculinities has struggled to take off. This chapter will survey work that has been done in this field and I will get into this question by reflecting on my own experiences of working across masculinity and politics over the last two decades. We will see that the field has very specific contours in modern British historiography, with particular chronologies and accounts of historical change. The second half of the chapter will then survey the key themes in the literature and will consider how the field is poised to develop in future.

Like many historians of masculinity, I did not start out as one. My PhD thesis began as a political study, exploring the emotive idea of 'independence' in the Georgian period. Like many postgraduate students in the 1990s, I was influenced by the linguistic turn's approach to social description and political traditions, ${ }^{1}$ and so I was seeking to explore the role of an important keyword in political life. As the doctorate became more focused on the notion of

The original version of this chapter was revised: For detailed information please see erratum. The erratum to this chapter is available at https://doi.org/10.1057/978-1-137-58538-7_21

M. McCormack $(\bowtie)$

University of Northampton, Northampton, UK

e-mail: matthew.mccormack@northampton.ac.uk

(C) The Author(s) 2018

C. Fletcher et al. (eds.), The Palgrave Handbook of Masculinity and Political

Culture in Europe, https://doi.org/10.1057/978-1-137-58538-7_12 
citizenship - how the legitimate political subject was defined socially, and how membership of the political nation was experienced-it became clear that the project was really about masculinity: how citizenship was associated with certain sorts of men, and how it excluded women and certain other men. ${ }^{2}$

By the time I finished my PhD I saw myself as a gender historian, but I found myself in a corner of gender history that was not very heavily populated. In British historical studies of the eighteenth and nineteenth centuries, the study of masculinity and politics was virtually a non-topic. The gender blindness of mainstream political history almost goes without saying, and this is likely the case in other national historiographies too. Men were ubiquitousthe MPs, the voters, the 'great men' and the 'men of letters'-so their gender was not considered worthy of note. The universal subject of political history is implicitly public and male. At the dawn of the eighteenth century, liberal contract theory consigned women to the invisibility of the private sphere, ${ }^{3}$ and to this day, most political histories of the period replicate this assumption.

Where British masculinities were concerned, the neglect of politics was all the more frustrating because it should not have been the case. Early interest in masculinity in Britain came partly from the men's liberation movement of the 1980s, where activists sought to critique the 'power we had inherited as men': this was emphatically a pro-feminist endeavour, since patriarchal roles and relationships were damaging to women and men alike. ${ }^{4}$ At the same time, academic feminists increasingly argued that men's roles were historically defined rather than fixed, shifting their focus to the cultural category of 'gender'. ${ }^{5}$ The role of men in the public sphere was explored brilliantly in Leonore Davidoff and Catherine Hall's foundation text for British gender history, Family Fortunes: Men and Women of the British Middle Classes, 1780-1850 (1987). Having engaged with the topic at its birth, however, British gender history rarely returned to it. Davidoff and Hall themselves published further key essays, ${ }^{6}$ and there were also notable studies focus focusing on nineteenth-century labour history $^{7}$ and the twentieth-century Conservative party. ${ }^{8}$ These pioneering works were not really followed up by other scholars, however, or joined up into a coherent field. Throughout the 1990s, therefore, the histories of masculinity and politics in Britain largely continued on their separate paths.

Arguably, the reasons for this lay in the prominence of the concept of 'separate spheres' in British women's history, and in the attempts to critique it that were bound up with the emergence of gender history. Within academic feminism, men's dominance of the public sphere was the corollary of women's subordination of the private. Since the pioneers of women's history were seeking to rescue women's experience from historical invisibility, critical attention was necessarily focused on the private sphere. The development of gender history often involved critical reflection on the methods and politics of women's history, ${ }^{9}$ and this work often emphasised the ways in which separate spheres did not apply in practice. ${ }^{10}$ Therefore gender histories of politics showed how women were present in the public sphere; and early work on British masculinities showed how men were present in the private world of the home. So the study of public masculinities continued to be sidelined, 
although there is a huge amount that it could gain from both of these literatures. Work on women and politics has highlighted the social and informal aspects of political life that are so often overlooked by mainstream political history. ${ }^{11}$ And John Tosh's manifesto for the history of masculinity emphasised that the home-the focus of his seminal A Man's Place: Masculinity and the Middle-Class Home in Victorian England (1999) — could only be understood in a triangular relationship with work and political association. ${ }^{12}$

At the beginning of the twenty-first century, the study of masculinity was very fashionable in British historical studies and a favourite topic for conferences. For example, the 'Father Figures: Gender and Paternity in the Modern Age' conference at Liverpool John Moores University in 2003 got a huge response to the call for papers: this was a sign of how far the history of masculinity had come and, in particular, was tribute to the impact of Tosh's work on the Victorian family man. ${ }^{13}$ Given the focus of the conference, papers on the 'public' side to masculinity were inevitably in a small minority. There was some discussion of how the critique of 'separate spheres' had possibly thrown the baby out with the bathwater, in losing sight of the need to distinguishand to understand the links - between these two gendered areas of activity. ${ }^{14}$ When I organised a conference on 'Public Men: Political Masculinities in Britain, 1700-2000' the following year, the number of proposals was much more modest, but was nevertheless excitingly rich. ${ }^{15}$ Tellingly, the vast majority of speakers were graduate students: usually a good sign of an emerging field. Besides historians of gender and/or politics, the conference attracted historians working on art, the police, empire, literature and economics. Indeed, many 'historians of masculinity' would in fact regard that as being a secondary disciplinary identity and employ 'masculinity' as a problematic alongside other considerations within historical studies. Far from being a handicap for the field, this oblique approach instead cautions against reifying something that is in fact provisional and slippery, and which is inevitably informed by other aspects of human experience.

Early work on British political masculinities therefore promised a significant new field of historical investigation. Although important studies have appeared over the last decade, however, the field remains somewhat diffuse and its impact on the wider historiography has been limited. This is possibly because the field still struggles to justify its existence. Do we really need more histories of 'great men'? Why is it 'new' to study an area of history that has always been dominated by men? And is there a danger that feminism could lose out by diverting its energies to study it? ${ }^{16}$ It is therefore necessary to take stock of the field and to make a renewed case for its usefulness.

\section{Periodisation}

Historians of political masculinities work across two fields that have very different attitudes towards periodisation. Political historians are very comfortable talking about long-term change, in relation to questions such as state development, political movements and ideological traditions. Whig and 
Marxist accounts of British political development had very clear teleologies and their influence continues to be felt. Even the 'new political history' that sought to critique them can be accused of turning Whig history's optimistic narrative on its head, in suggesting that individual freedom was in fact restricted by the onward march of liberalism. ${ }^{17}$

Historians of masculinity are, by contrast, less comfortable with the longue durée, and not just because they work in a less established field. The history of masculinity is, in part, a product of the cultural turn in historical studies, which usually concerns itself with deconstructing metanarratives rather than building them up. Its subjective and personal subject matter often lends itself to article-length case studies (such as the contributions to this collection) that focus on individuals, moments or crises. John Tosh has protested that this 'has the effect of dissolving any sense of trajectory or process' and that historians need to restore the long view in order to discern the 'large themes, which may not be visible to the cultural analyst working on a particular moment in time' ${ }^{18} \mathrm{He}$ proposed that the history of gender in the nineteenth century should be linked to those of industrial development and imperial expansion in order to restore such a perspective-but surely the history of politics offers at least as good an opportunity (and without the Marxist underpinnings).

Nor is cultural history necessarily the problem here: a handful of booklength studies have since combined gender and politics chronologies in order to explore the long view. ${ }^{19}$ Indeed, probably the most ambitious recent attempt to think about masculinity across periods and borders is very much in the mould of cultural history. Christopher Forth's Masculinity in the Modern West takes issue with the notion of 'crises of masculinity' and argues that masculinity has never been 'non-critical'. He argues that, when men become 'modern', they become distanced from the conditions of struggle and discomfort that constitute authentically 'masculine' practices and habits. ${ }^{20}$ In terms of politics, his perspective is particularly useful when considering political movements whose stated aim is to 'reclaim' masculinity, such as revolutionary movements of the eighteenth century, muscular Christianity or popular imperialism in the nineteenth, or fascism in the twentieth.

Where the history of masculinity is concerned, however, there remain obstacles to working across periods. Masculinities look very different in different periods of history. Historians of the seventeenth and nineteenth centuries tend to emphasise an anxious, godly and patriarchal model of manhood; whereas historians of the eighteenth and twentieth centuries instead emphasise a more fluid masculinity that is flamboyant, sexualised and publicly validated. This may signify a cyclical pattern in the history of masculinity-an ebb and flow between two fundamental poles (not that these features are mutually exclusive: it is possible to be both godly and sexualised, for example). Or it may instead simply be the case that different sorts of historians work on different centuries and therefore find it difficult to look beyond 
their period silos. In British studies, the seventeenth and nineteenth centuries have long been dominated by social and economic history. By contrast, the eighteenth and twentieth centuries were relatively neglected until recently, so interdisciplinary cultural studies rushed into fill the vacuum. ${ }^{21}$ This arguably accounts for the unevenness of the attempt to take stock of the field in the 2005 special feature on masculinities in the Journal of British Studies, where Tosh's plea to reclaim the history of masculinity for Victorian social history sat uneasily with Michèle Cohen and Michael Roper's use of cultural methodologies on the adjoining centuries. ${ }^{22}$

Nevertheless, it is possible to sketch the broad contours of political masculinity in Britain over the eighteenth and nineteenth centuries. At the beginning of the period, masculinities were relatively fluid, within a scheme of sex difference that was on a sliding scale. ${ }^{23} \mathrm{~A}$ range of masculine identities were available - such as the libertine, the polite man or the homo religiosus - and men were adept at performing different personas in different situations. ${ }^{24}$ These personas did not necessarily define who you were, and a politician's private morality was not regarded as having a bearing on his public life. As such, the primary political masculinity of the early modern period was that of the courtier, who possessed the refined and codified manners of the European aristocracy. Paul Langford has shown how elite politicians in the early eighteenth century adopted an 'if you've got it, flaunt it' attitude: portraits of statesmen like Sir Robert Walpole displayed them in all of their official glory, 'robed, ribboned, decorated'. ${ }^{25}$ The code of politeness carried refined manners further down the social scale, but the gentry and the middling sorts tended to adopt a plainer and more businesslike attitude towards masculinity, as embodied in their new uniform, the sober three-piece suit. ${ }^{26}$

As the century wore on, those excluded from the centre of power became more assertive in their criticisms of the establishment. They argued that they were more deserving of office than the narrow ruling elite, and often did so in terms of nationalism and gender. They asserted the rights of 'the country' and 'the people' against those who were culturally foreign: denizens of the German court who were addicted to fine French foods and Italian opera. This went hand in hand with accusations of 'effeminacy' - not femininity or homosexuality as such, but a failure of the moral qualities associated with virtuous masculinity. ${ }^{27} \mathrm{By}$ asserting that the political 'ins' were unpatriotic and morally degenerate, the political 'outs' simultaneously undermined the current establishment's right to rule and trumpeted their own. This highly gendered political culture drew heavily on classical republicanism, which asserted that the true source of power in a state lay in its citizenry of substantial householders. The strength of the polity lay in the virtue and vigilance of these citizens, since a weak populace could be overawed by an oppressive ruler or foreign threats. The crucial masculine quality of this citizenry was 'independence', based upon landed property, martial capability and love of liberty: people in a dependent relationship, such as women, children, the poor or the infirm, did 
not have the freedom of conscience or action to stand up for the public good. Historians of political thought such as J.G.A. Pocock have long argued for the influence of neoclassical republicanism in this period, ${ }^{28}$ but gender historians have shown just how far it impacted on everyday society and politics. The Georgian patriarch - with his property, his parliamentary vote and his 'little republic' of a household - was apt to identify with these ideals. ${ }^{29}$

The period of the Seven Years War (1756-1763) can be seen as a watershed in several respects. The early stages of the war went badly for Britain, so 'patriot' criticisms of the ruling establishment reached a new height. Admiral Byng failed to engage a larger French fleet, leading to the fall of Minorca, and became the symbol of the unpatriotic and unmanly ruling class. The government attempted to scapegoat Byng, court martialling him for cowardice and executing him on the deck of his ship, but this did not head off the wider critique. Anti-establishment politics focused on the movement to reform the militia, which revelled in the image of the manly householder who would defend all that was dear to him as a husband, a father, a patriot and a Protestant. ${ }^{30}$ The politician who benefitted most from the sense of crisis was the Elder Pitt, who rode to power on a wave of patriotic enthusiasm. The first 'popular' prime minister, 'The Great Commoner' projected a masculine image that was patriotic, sincere and above the blandishments of party politics. $^{31}$

Several gender historians point to George III's accession in 1760 as the specific turning point: political events can therefore drive gender change. ${ }^{32}$ George installed the Tories and ejected the Whigs, and those who were now excluded from government became assertive in their criticisms of it. In particular, John Wilkes used print journalism and demotic election contests in order to appeal to the extra-parliamentary nation. Wilkes reworked the old opposition 'patriotism' in increasingly radical ways, so that even humble men could imagine themselves as citizens who deserved rights such as the vote. His own colourful hypermasculinity became central to his cause. His virulent xenophobia was a populist stance against the Scottish prime minister Bute, his fondness for duelling and militia service underlined his martial credentials, and even his libertine sexuality came to embody his commitment to political liberty. ${ }^{33}$ At the same time, Marilyn Morris argues that the beginning of George III's reign represents a sea change in terms of the personalisation of politics: 'Young, British-born and chaste, the king raised expectations of national moral regeneration.' Unlike his predecessors, he became a popular and identifiable figure, with a reputation for marital fidelity and virtuous domesticity - issues that, Morris argues, would hardly have been relevant to a monarch or statesman in the early eighteenth century. ${ }^{34}$

Arguably George III anticipated the way British politics was going, because after the 1770s politicians were increasingly required to be virtuous in both their public and private lives. ${ }^{35}$ The catastrophic loss of America plunged the nation into a bout of soul searching, and attention focused once 
again on the moral fitness of elite politicians. Even John Wilkes had to reinvent himself as a 'reformed rake' and a family man when he sought to become Lord Mayor of London. For Dror Wahrman, the fallout from the American War created a crisis of identity for Britons. He characterises the later eighteenth century as a time of 'gender panic', when the loose and playful identities of the early modern world were finally closed down and replaced with a modern notion of self: your social being was expected to reflect who you actually were in biological, sexual and racial terms. ${ }^{36}$ Wahrman's chronology complements other chronologies within the histories of gender, sexuality and medicine, which suggest that fluid notions of gender difference were replaced by a strict binary scheme in which women were subordinate and conjugal heterosexuality was the norm. Men's political dominance was therefore justified not by tradition and biblical precept, but was declared 'natural' by the new science of the Enlightenment. ${ }^{37}$

The French Revolution had profound implications for politics and gender in Britain. Politics became polarised between radical supporters of Revolution and conservative defenders of the status quo. This was the heroic age of working-class radicalism celebrated by Marxist historians like E.P. Thompson, where proud artisans railed against industrialisation and injustice, and educated themselves in the rights of man. Gender historians such as Anna Clark have presented a less heroic picture, suggesting that Thompson marginalised women in his narrative, and that his artisans were hostile to female labour and were given to misogyny and violence. ${ }^{38}$ Indeed, when radicals talked about the rights of 'men', they often meant just that. In order to make the case that all men possessed the 'independence' required of political personhood, they lumped together women, minors and the insane as 'dependent' people who lacked the required situation and capability. Redrawing citizenship in inclusive social terms often meant being exclusive in terms of gender. ${ }^{39}$

Loyalist ideas about gender were no less significant. Desperate to mobilise civilian men for military service against the threatened French invasion, the establishment appropriated patriotism from the radicals, presenting martial citizenship as the masculine ideal—a model of citizenship that excluded women, who were instead presented as helpmeets and objects to be defended. Women's historians have long identified the 1790s as being at the root of nineteenth-century gender codes. ${ }^{40}$ George III responded to the French Revolution's assault on traditional hierarchies by 'endorsing a model of manliness based on familial responsibility'. ${ }^{41}$ The Tory counter-revolution combined with evangelical Christianity to imbue the new middle classes with an ideology based upon domestic virtue, industry and godliness. Only a virtuous nation that protected its womenfolk could hope to prevail against the atheists: 'separate spheres' was therefore a highly political ideology rather than a social structure as such. Nor was it just reactionary, since it was also a way for the middle classes to trumpet their moral superiority to those socially 
above and below them, and thence to push for political rights to match their newfound economic power.

The radical movement rallied at the close of the Napoleonic Wars, which brought about widespread unemployment and economic dislocation. Men who had served their country in war argued that they had performed a key duty of citizenship, and so deserved its rewards. ${ }^{42}$ The climax to postwar radical activity was the Queen Caroline Affair of 1820, when George IV attempted to divorce his estranged wife prior to his coronation. Political historians long failed to take this 'affair' seriously, since it appeared to epitomise the worst excesses of royal sex scandals. Gender historians, however, have shown how these ideas about masculinity were 'not merely an adjunct to more serious political concerns... they were political in themselves' ${ }^{43}$ Radical and Whig critics of the establishment were able to mobilise a huge popular movement behind Caroline, which highlighted important issues such as legal oppression, women's rights within marriage and the unrepresentativeness of parliament. Moreover, ideas about sex and gender gave their critique much of its appeal. George treated Caroline unchivalrously and failed to establish a harmonious household: his private failings were central to his public reputation. Within the dramatis personae of popular melodrama, George was portrayed as a debauched aristocratic villain, Caroline an innocent heroine, and her (male) champions as chivalric heroes. Clark argues that the affair was a turning point in political aesthetics, as satire came to be replaced by melodrama: the 1820s saw the last hurrah of scabrous, bawdy Georgian satire and ushered in a more respectable political culture. ${ }^{44}$ This involved a new model of statesmanship that was very different to the court politician of old. Langford suggests that the nineteenth-century legislator was 'discreet in manner, unpretentious in appearance, reserved if not cold, keeping his warmth for his home and hearth, disdainful of men and their wants, devoted to public duties'. ${ }^{45}$

When parliamentary reform finally came in 1832 it was similarly concerned with domestic respectability. The Whig Reformers had a very clear idea of those to whom it wished to give the vote, since they believed that greater political liberty consisted not of giving the vote to more people, but to the right people, whom they deemed able to exercise it responsibly. So although the size of the electorate expanded by about 50 per cent, it became more socially exclusive: the old haphazard system of local qualifications (in which many working people could vote) was superseded by a uniform property qualification (which intended to give the vote to middle-class men). The dividing line between citizens and non-citizens was the old constitutional benchmark of 'independence', now reworked for an era of domestic propriety. Voters should not only possess property, but should be 'married men and the fathers of families', since their familial and domestic situations guaranteed their respectability, responsibility and capacity for government. ${ }^{46}$ Moreover, the electoral citizen was legally defined as being male for the first 
time. Political historians who regard the 1832 Reform Act as having a crucial role in defining the Victorian citizen make much of this, but Kathryn Gleadle has queried its impact in practice. Women could not vote anyway under the old system; the parallel Reform Act for Scotland had no such proscription; and the same parliament passed the 1831 Vestries Act, which did allow female participation. ${ }^{47}$ Either way, gender history informs a key moment in the British political chronology: did 1832 represent progress (Whig history), continuity (revisionism) or an attempt to restrict political freedom (new political history)?

Working men who had long campaigned for the vote were not rewarded in 1832, so radical energies in the 1830s and 40s focused on Chartism. Chartism has a huge status in labour history since this was the first nationwide working-class political movement. It was long interpreted as a proto-socialist movement with social and economic goals, but more recent political historians have emphasised its political nature and its debt to the old radical movement. ${ }^{48}$ Their goal was the People's Charter, which made exclusively political demands: they believed that the vote was the key to achieving change, since a representative parliament would pass good laws, which would result in a fairer society. Like their radical forebears, however, they believed that voting was the preserve of men: only men possessed the crucial quality of independence, now reworked to encompass labour as well as property. Chartists deployed a gendered rhetoric that celebrated the male breadwinner and the benefits for women of domestic respectability. ${ }^{49}$ In R.W. Connell's terms, they arguably positioned themselves in a 'complicit' relationship with the hegemonic masculinity of the middle classes, rather than challenging it. ${ }^{50}$

Chartism had fizzled out by the 1850s but the reform tradition continued in the Victorian Liberal party. Parliamentary reform was back on the agenda in the 1860s and the story of how the Second Reform Act of 1867 came to be passed dominates Victorian political historiography. Whig historians try to claim the Act for the progressive Liberal tradition and Tory historians celebrate the way that Benjamin Disraeli outwitted the Liberals to pass a Conservative Bill instead, but gender historians have presented a more sceptical interpretation of the Act. Catherine Hall, Keith McClelland and Jane Rendall brought the perspectives of empire, masculinity and women to the debates of 1867, showing how the Act 'defined the Victorian nation' in terms of race, class and gender. The citizen of 1867 was the British working man, and people who failed to meet these three criteria were deemed unsuitable for citizenship. ${ }^{51}$ On the other hand, the parliamentary history of women's suffrage did begin in earnest, when the Liberal MP and feminist John Stuart Mill proposed that 'man' should be replaced with 'person' in the wording of the bill. Women's suffrage is usually the point in British history when political historians start to take gender seriously, since women were seeking to participate in the official structures of politics with which political history tends to be concerned. Even here, however, masculinity is crucial. Ben Griffin has proposed 
that we can only understand the political fortunes of women's suffrage if we attend to the masculinity of the men who were voting on these issues in parliament, since suffragism struck at the heart of the patriarchy in which MPs (of all people) had a stake. ${ }^{52}$

The new mass electorate transformed political culture since political parties had to change the basis of their appeal and the way that they communicated. Gender history has shed light on the differences between Liberal and Tory political cultures in this period, since they arguably projected competing models of masculinity. ${ }^{53}$ Nonconformists and former Chartists found a home in Gladstone's Liberal Party. Gladstone became a cult figure among many working men, who identified with his work ethic, his moral character and his belief in rewarding self-improvement and combating privilege. ${ }^{54}$ Working men who found the Liberals too censorious instead gravitated towards the Conservative Party of Benjamin Disraeli, who had the polar opposite masculinity to his rival across the dispatch box. His flamboyance and romanticism was projected onto his party, which created a heady brew of monarchism, imperial nationalism and popular Anglicanism. If a working man wished to have a drink, bet on a horse or doff his cap to his betters, then those were his rights as a freeborn Englishman. ${ }^{55}$ The Conservative Party was also notably more welcoming to women and brought hundreds of thousands of women into its ambit via the Primrose League. This is not to say that the late-Victorian Conservative Party was a hotbed of feminism: rather they were pragmatic about whence they drew their support, and they appreciated the role that elite women had always played in electioneering (something that became all the more important when the electoral rules tightened in 1883). The Liberals were by contrast more doctrinaire in their gender politics. Although they harboured prominent feminists like Mill, they also included some key anti-suffragists and represented a continuity of the radical tradition that protected the rights of the male breadwinner. This emphasis was even more pronounced in the gender politics of the Trade Unions and the nascent Labour Party. We therefore have to look to the nineteenth century if we are to explain why proportionately more women were drawn to the Conservative Party in the twentieth. ${ }^{56}$

At the close of the nineteenth century the world of electoral citizenship was symbolically male, but this did not always play out in practice. The Third Reform Act of 1884-1885 appeared to grant universal male suffrage, but stringent residency requirements excluded around 40 per cent of adult males. The old ideal of the householder citizen remained, so mobile workers, male servants, bachelors who did not have their own home, and soldiers in barracks remained excluded. The latter was especially ironic, since this era of strident imperialism celebrated martial attributes in men. Sonya Rose argues that 'brute force and military service took the place of property, independence and respectability in the public culture of masculinity and citizenship'. ${ }^{57}$ This aligns with John Tosh's chronology for Victorian manliness, whereby in 
the latter stages of the century men turned their backs on domesticity and revelled in fantasies of imperial adventure. ${ }^{58}$ Although radicals had argued for a century that service to the nation should be rewarded with the vote, common soldiers had to wait with women until after the First World War to become full citizens.

\section{THEMES}

This brief synthesis shows that, although work on British political masculinities has often been diverse and compartmentalised, it is possible to connect it up into a coherent field. Moreover, if we combine chronologies from the histories of politics and gender, we can think about change over the longue durée. With this perspective, various long-term changes can be discerned over the eighteenth and nineteenth centuries: the evolving gendered definition of the electoral citizen; the increasing sense that masculinity and femininity are incommensurate categories with different spheres of activity; the changing model of masculine statesmanship; and the increasing sense in which a man's private life is relevant to his public one. At the same time, we can also see key continuities: the 'radical continuum' from early radicalism via the Liberal Party into the Labour Party, with all of its associated masculinism; the enduring influence of classical notions of virtue and corruption; their equation of citizenship with household proprietorship and forms of 'independence'; and the persisting power of military citizenship, along with the failure to align political citizenship with men who actually serve. In general, although the precise bases and manifestations of it may change, the fundamental connection between politics and masculinity is assumed throughout the period.

Further themes could be developed from this survey. The account of citizenship here is mostly concerned with its changing definition and its representation in public discourse. But we also have to bear in mind that citizenship is a lived condition. Rose argues that the language of citizenship 'produces political subjectivities' which people enact and feel. ${ }^{59}$ Given that citizenship involves membership of a community, strong emotions come into play when that community is under threat-one reason for the enduring power of military citizenship in Britain. Studies of women's citizenship also remind us that citizenship is a day-to-day experience, and Gleadle argues that historians need more dialogue with sociologists and psychologists if they are going to develop a nuanced understanding of such 'micro-level' political interactions. She further cautions that political historians often read sources too literally, giving a misleading impression of a totally masculine public sphere. For example, women may not be listed as attendees at political dinners, but they might well have attended after the food for the speeches. Or Victorian authorial conventions often mean that a man is named as the author of a political treatise, which might well have been the product of collaboration with other family members. ${ }^{60}$ 
As such, there are opportunities for the history of masculinity to say more about the nature of political practice. Masculinity is at its most concrete at the level of the corporeal, and the bodiliness of British politics is often striking. The rough-and-tumble of the parliamentary election contest provided an arena where the manliness of aspiring public servants was put to the test. We mostly associate this with the age of Hogarth, but Kit Good and Jon Lawrence have shown how this persisted into the nineteenth century and beyond. ${ }^{61}$ The canvass is still a spontaneous and interactive arena where politicians are expected to think on their feet, and to deal with physically or verbally aggressive ambushes from the public.

Political speaking, too, is a physical act. Griffin notes that 'the masculinity of politicians was constantly being assessed, not only by reference to what they said, but also by their dress, deportment and manners'. ${ }^{62}$ It is all too easy to forget this when our sources for political speeches from this period are texts on the page. Occasionally, these sources give an impression of how a speech was performed, giving us an insight into the bodiliness of political speaking. For example, take this report of Robert Grant speaking at the 1830 Norwich election: 'Mr. G's stature is lofty, and his deportment grave and commanding. - His voice and manner are alike dignified, and his style copious and rich. There is something peculiar in his manner of address that cannot fail to secure the attention of his hearers. ${ }^{63}$ Illustrations of political speakers show just how theatrical verbal communication could be in a period when the body was seen as a window on the soul. Gladstone was an avid student of John Walker's The Academic Speaker (1797), which provided illustrations of the bodily attitudes that convey the ideas being spoken: sketches of Gladstone speaking in the Commons suggest that he put these prescriptions into practice. ${ }^{64}$ Recent works have shed light on the specific rhetorical culture of the British parliament and its implications for masculinity. ${ }^{65}$ In particular, the choice of the term 'maiden speech' is telling, suggesting that it is 'something akin to that first trip to a brothel in the company of male relations or friends for performance of that act that will make him a man'. ${ }^{66}$

Masculinity can provide similar insights into the world of political ritual. Ritual is one area of British history where political historians have long had to engage with sociological methodologies. For example, Frank O'Gorman's classic essay on election rituals and ceremonies predates historical interest in political masculinity, but forms the backdrop for more recent work that has tried to think about the gendered nature of electoral performance. ${ }^{67}$ Histories of political women have highlighted the ritual aspects to the sociable side to politics in this period, notably the gendered activities of visiting and entertaining. ${ }^{68}$ Masculinity is especially interesting in homosocial contexts such as associations and dinners, or when studying the meetings that radicals and loyalists alike held in taverns. ${ }^{69}$ Drinking rituals can shed light on the emotional (and chemical) ways in which political bonds are created between men. Karen Harvey has explored the world of the eighteenth-century punch party, where men from the middling sorts would gather privately to drink from a large 
decorated bowl. She cautions that sociable experiences like this are difficult to reconstruct, but the strict rules and rituals of such occasions nevertheless shed light on unwritten masculine codes.

This brings us to the history of material culture, since Harvey places a lot of emphasis on the punchbowl itself. The cost of the bowl and its liquid contents tell us about the sorts of men who would have participated, and the rich decorations on the bowls commonly reference all-male political associations like militias, guilds or clubs. Furthermore, the materiality of the bowl tells us about its use and effect: 'circular and open bowls enable sharing and coming together', as would the practice of passing the bowl from man to man. ${ }^{70}$ Objects therefore have agency and perform cultural work. In some political contexts, objects can have clandestine meanings: objects with hidden images or texts, or references that would only be meaningful to fellow initiates, helped to sustain the underground movements of Jacobitism and Jacobinism. ${ }^{71}$ More overtly, public memorials and keepsakes like tokens and medals commemorated men's involvement in loyalist and military associations. ${ }^{72}$

Rituals take place within spaces, and approaches from the spatial turn can shed light upon the gendering of politics. The 'separate spheres' interpretation lent itself to thinking about the home as a space, but as an apolitical one, so gender historians and political historians alike were long remiss in considering this aspect. But Zoe Dyndor's recent study of electioneering in the eighteenth century shows that the home space could be a very political arena. The receiving of candidates into the home was a ritualised process; and in certain boroughs, the question of whether a dwelling would confer a vote was spatially defined, hinging on questions like whether it opened directly onto a street, or whether a pot could be boiled within. At election time, these spatial questions had big implications for a male householder's access to electoral citizenship, or a female landlady's ability to influence proceedings (and to earn extra rent). ${ }^{73}$ Various everyday domestic rituals could have a political character, such as the reading of news, writing letters on behalf of the family, or family prayers. ${ }^{74}$ Shifting from the micro to the macro, the geography of political activity is also important. The history of masculinity has generally been very urban in its focus: this is understandable, given that topics like homosexuality, politeness or bourgeois domesticity usually presuppose an urban backdrop. Early attempts to integrate masculinity into a wider political narrative often let the urban experience stand for the nation as a whole, without really thinking about the specificity of its conditions. ${ }^{75}$ The rural, however, is making a comeback. Harvey notes that eighteenth-century masculinities should encompass 'the patriotic country squire or the backbench Tory', as well as more colourful urban figures like the fop or the man of the coffeehouse. ${ }^{76}$ And our understanding of gender and politics in the nineteenth century has also been enhanced by recent studies of the rural gentry. ${ }^{77}$

This section has largely focused on forms of political practice, since much of the best recent work on British political masculinity has used this approach, and suggests that the field has the potential to develop further in this way. 
The history of masculinity need not therefore be limited to representationbut, at the same time, political historians should not dismiss the insights of the linguistic turn, or lose the ability to read language in a nuanced way. One final question that a recent study has raised is the role of political rhetoric in masculinities. Stephen Moore has explored the Admiral Byng controversy, which gender historians have argued was part of a wider panic about gender relations and the moral fibre of the ruling class. Moore, on the other hand, argues that Byng's alleged effeminacy was rather a 'rhetorical strategy' by a government that was determined to scapegoat him: gender was not 'the central trope motivating public discussion, nor was the discussion reflective of a broader concern for waning masculinity' ${ }^{78}$ In this instance I disagree: in general, the cultural historian in me is minded to assume that, where gendered rhetoric is present, then it is likely to be having an ideological effect. The history of political masculinities cannot be boiled down to deliberately chosen words and images: if nothing else, these can only have an effect within a political culture where gender is important. But political historians are well placed to assess the intentionality in statements of masculinity. When Gladstone posed for a photographer in his shirt-sleeves and resting on an axe, he knew what image he was seeking to convey and endeavoured to control it. ${ }^{79}$

In conclusion, the question mark in the title is employed advisedly, since it is necessary to query the way that men in British politics have traditionally been studied. Politics in the eighteenth and nineteenth centuries was long regarded as 'a man's sphere', but work on gender and masculinity over the last quarter-century has done much to nuance our understanding of men's political roles. We have seen that there is much to be gained in openly critiquing something that is silently assumed. This can help us to understand both men's historical dominance and the nature of the British political systemand, indeed, it often demonstrates that the public sphere was by no means as uncomplicatedly male as our sources would often have us believe. The study of political masculinity is therefore a feminist endeavour, rather than being a threat to it. Equally, work on political masculinities has the potential to inform the history of masculinity more widely, since politics is a field where ideology and practice are both crucial: the history of masculinity need not then be restricted to representation, or to the short term. Although the field remains somewhat underdeveloped, work on British political masculinities in this period suggests that it could yet be a very significant area of historical investigation.

\section{Notes}

1. J. Vernon, 'Who's afraid of the linguistic turn? The politics of social history and its discontents', Social History 19: 1 (1992), 81-87.

2. M. McCormack, "The Idea of "Independence" in English Political Culture, c. 1760-1832' (unpublished PhD thesis, University of Manchester, 2002). 
This became The Independent Man: Citizenship and Gender Politics in Georgian England (Manchester: Manchester UP, 2005).

3. C. Pateman, The Sexual Contract: Aspects of Contractual Liberalism (Stanford: Stanford University Press, 1988).

4. V. Seidler (ed.), The Achilles Heel Reader: Men, Sexual Politics and Socialism (London: Routledge, 1991), p. ix.

5. J. Scott, 'Gender: a Useful Category of Historical Analysis', American Historical Review 91: 5 (1986), 1053-1075.

6. See their respective collections Worlds Between: Historical Perspectives on Gender and Class (London: Polity, 1995) and White, Male and Middle Class: Explorations in Feminism and History (London: Polity, 1992).

7. A. Clark, The Struggle for the Breeches: Gender and the Making of the British Working Class (London: Rivers Owen, 1995); K. McClelland, 'Some Thoughts on Masculinity and the "Representative Artisan" in Britain, 18501880', Gender \& History l (1989), 164-177.

8. J. Lawrence, 'Class and Gender in the Making of Urban Toryism, 1880-1914', English Historical Review 108: 2 (1993), 629-652; David Jarvis, 'The Conservative Party and the Politics of Gender, 1900-1939', in M. Francis and I. Zweiniger-Bargielowska (eds), The Conservatives and British Society, 18801990 (Cardiff: University of Wales Press, 1996), pp. 172-193.

9. A. Vickery, 'Golden Age to Separate Spheres? A Review of the Categories and Chronology of English Women's History', The Historical Journal, 36: 2 (1993), 383-414.

10. See, for example: M.J. Petersen, 'No Angels in the House: the Victorian myth and the Paget Women', American Historical Review, 89: 3 (1984), 677-708; R. Shoemaker, Gender in English Society 1650-1850: The Emergence of Separate Spheres? (Harlow: Longman, 1998), pp. 305-318.

11. K. Gleadle and S. Richardson (eds.), Women in British Politics, 1760-1860: The Power of the Petticoat (Basingstoke: Macmillan, 2000); A. Vickery (ed.), Women, Privilege and Power: British Politics, 1750 to the Present (Stanford: Stanford University Press, 2001).

12. J. Tosh, 'What Should Historians do with Masculinity?', History Workshop Journal 38 (1994), 179-202.

13. A selection of papers from the conference were published as T.L. Broughton and H. Rogers (eds.), Gender and Fatherhood in the Nineteenth Century (Palgrave: Basingstoke, 2007).

14. Karen Harvey has since explored how men's statuses, roles and material experiences in the house related to politics in The Little Republic: Masculinity and Domestic Authority in Eighteenth-Century Britain (Oxford: Oxford University Press, 2012).

15. A selection of papers from the conference were published as M. McCormack (ed.), Public Men: Masculinity and Politics in Modern Britain (Palgrave: Basingstoke, 2007).

16. Stefan Dudink, Karen Hagemann and Anna Clark reflect on these issues in the preface to their collection Representing Masculinity: Male Citizenship in Modern Western Culture (Palgrave: Basingstoke, 2007), p. xvi.

17. For example: J. Vernon, Politics and the People: A Study in English Political Culture 1815-1867 (Cambridge: Cambridge University Press, 1993). 
18. J. Tosh, 'Masculinities in Industrialising Society: Britain, 1800-1914', Journal of British Studies 44 (2004), 330-342 (p. 330). Tosh has subsequently expressed his concern that cultural history has become 'the historical paradigm' and has argued that the history of masculinity should instead return to 'its moorings in social experience': 'The History of Masculinity: An Outdated Concept?', in J. Arnold and S. Brady (eds.), What is Masculinity? Historical Dynamics from Antiquity to the Contemporary World (Palgrave: Basingstoke, $2011)$, pp. 20, 31.

19. A. Clark, Scandal: The Sexual Politics of the British Constitution (Princeton: Princeton University Press, 2004); McCormack, Independent Man; Harvey, Little Republic; B. Griffin, The Politics of Gender in Victorian Britain: Masculinity, Political Culture and the Struggle for Women's Rights (Cambridge: Cambridge University Press, 2012); H. French and M. Rothery, Man's Estate: Landed Gentry Masculinities, 1660-1914 (Oxford: Oxford University Press, 2012); Marilyn Morris, Sex, Money \& Personal Character in Eighteenth-Century British Politics (New Haven: Yale University Press, 2014).

20. C. Forth, Masculinity and the Modern West: Gender, Civilisation and the Body (Palgrave: Basingstoke, 2008), pp. 3-5.

21. This is reflected in professional bodies for historians in Britain. Whereas historians of the nineteenth century are strongly represented in the Social History Society, their eighteenth-century counterparts tend to gravitate towards the interdisciplinary British Society for Eighteenth-Century Studies.

22. 'What have historians done with masculinity? Reflections on five centuries of British History, circa 1500-1950', Journal of British Studies 44: 2 (2005) featuring contributions by Alexandra Shepard, Karen Harvey, Michèle Cohen, John Tosh and Michael Roper.

23. T. Laqueur, Making Sex: Body and Gender from the Greeks to Freud (Cambridge MA: Harvard University Press, 1992).

24. P. Carter, 'James Boswell's manliness' in M. Cohen and T. Hitchcock (eds.), English Masculinities, 1600-1800 (Harlow: Longman, 1999), pp. 111-130.

25. P. Langford, 'Politics and Manners from Sir Robert Walpole to Sir Robert Peel', Proceedings of the British Academy 94 (1997), 103-125 (p. 109).

26. D. Kuchta, The Three-Piece Suit and Modern Masculinity: England, 1550-1850 (Berkeley: University of California Press, 2002).

27. P. Carter, "An "effeminate" or an "efficient" nation? Masculinity and eighteenth-century social documentary', Textual Practice 11: 3 (1997), 429-443.

28. J.G.A. Pocock, The Machiavellian Moment: Florentine Political Thought and the Atlantic Republican Tradition (Princeton: Princeton University Press, 1975).

29. McCormack, Independent Man; Harvey, Little Republic.

30. M. McCormack, 'The New Militia: War, Politics and Gender in 1750s Britain', Gender \& History 19: 3 (2007), 483-500.

31. K. Wilson, The Sense of the People: Politics, Culture and Imperialism in England, 1715-1785 (Oxford: Oxford University Press, 1995), p. 193.

32. Clark, Scandal, p. 15; McCormack, Independent Man, p. 80.

33. J. Sainsbury, John Wilkes: The Lives of a Libertine (Farnham: Ashgate, 2006).

34. Morris, Sex, Money e Personal Character, p. 59.

35. Griffin, Politics of Gender, p. 39.

36. D. Wahrman, The Making of the Modern Self: Identity and Culture in Eighteenth-Century England (New Haven: Yale University Press, 2004). 
37. Laqueur, Making Sex.

38. A. Clark, The Struggle for the Breeches: Gender and the Making of the British Working Class (London: University of California Press, 1995), pp. 2-5.

39. McCormack, Independent Man, pp. 207-208.

40. C. Hall, 'The early formation of Victorian domestic ideology', in S. Burman (ed.), Fit Work for Women (London: Croom Helm, 1979), pp. 15-32.

41. Morris, Sex, Money \& Personal Character, p. 59.

42. L. Colley, Britons: Forging the Nation, 1707-1837(New Haven: Yale University Press, 1992), p. 318.

43. L. Carter, 'British Masculinities on Trial in the Queen Caroline Affair of 1820', Gender \& History 20: 2 (2008), 248-269 (p. 265).

44. Clark, Scandal, p. 219.

45. Langford, 'Politics and Manners', p. 118.

46. M. McCormack, 'Married Men and the Fathers of Families: Fatherhood and Franchise Reform in Britain', in H. Rogers and T. Broughton (eds.), Gender and Fatherhood in the Nineteenth Century (Houndmills: Palgrave, 2007), pp. $43-54$.

47. K. Gleadle, Borderline Citizens: Women, Gender and Political Culture in Britain, 1815-1867 (Oxford: Oxford University Press, 2009), p. 159.

48. G. Stedman Jones, Languages of Class: Studies in English Working Class History, 1832-1982 (Cambridge: Cambridge University Press, 1984).

49. Clark, Struggle for the Breeches, ch. 12.

50. R.W. Connell, Masculinities (Cambridge: Polity, 1995), p. 76.

51. C. Hall, K. McClelland and J. Rendall, Defining the Victorian Nation: Class, Race, Gender and the British Reform Act of 1867 (Cambridge: Cambridge University Press, 2000).

52. Griffin, Politics of Gender.

53. M. McCormack and M. Roberts, 'Chronologies in the History of British Political Masculinities, c. 1700-2000', in McCormack (ed.), Public Men, pp. 187202 (p. 194).

54. E. Biagini, Liberty, Retrenchment and Reform: Popular Liberalism in the Age of Gladstone, 1860-1880 (Cambridge: Cambridge University Press, 1992).

55. J. Lawrence, 'Class and Gender', p. 638.

56. M. Pugh, The Tories and the People: 1880-1935 (Oxford: Blackwell, 1985); B. Campbell, Iron Ladies: Why do Women Vote Tory? (London: Virago, 1987).

57. S. Rose, 'Fit to Fight but not to Vote? Masculinity and Citizenship in Britain, 18321918', in Dudink et al. (eds.), Representing Citizenship, pp. 131-150 (p. 145).

58. Tosh, Man's Place, ch. 8.

59. Rose, 'Fit to Fight', p. 133.

60. Gleadle, Borderline Citizens, pp. 4, 14, 63, 225.

61. K. Good, “"Quit Ye Like Men”: Platform Manliness and Electioneering, 18951939', in McCormack (ed.), Public Men, pp. 143-164; J. Lawrence, Electing Our Masters: The Hustings in British Politics from Hogarth to Blair (Oxford: Oxford University Press, 2009).

62. Griffin, Politics of Gender, pp. 188-189.

63. The Norwich Election Budget (Norwich, 1830), p. 18.

64. R. Cleaver, 'Some Gladstonian Attitudes: Sketches in the House of Commons' (1898), reproduced in Peter Jagger (ed.), Gladstone (London: Hambledon, 1998), frontispiece. 
65. C. Reid, Imprison'd Wranglers: The Rhetorical Culture of the House of Commons 1760-1800 (Oxford: Oxford University Press, 2012); Griffin, Politics of Gender, ch. 6.

66. Morris, Sex, Money \& Personal Character, p. 80.

67. F. O'Gorman, 'Campaign Rituals and Ceremonies: The Social Meaning of Elections in England, 1780-1840', Past and Present 135 (1992), 79-115; Vernon, Politics and the People; McCormack, Independent Man, ch. 2; Good, 'Quit Ye Like Men'.

68. See n. 10, above.

69. K. Navickas, "The "Spirit of Loyalty": Material Culture, Space and the Construction of an English Loyalist Memory, 1790-1840' in A. Blackstock and F. O'Gorman (eds.), Loyalism and the Formation of the British World 1775-1914 (London: Boydell, 2014), pp. 43-59 (p. 57).

70. K. Harvey, 'Ritual Encounters: Punch Parties and Masculinity in the Eighteenth Century', Past and Present 214 (2012), 165-202 (p. 197).

71. M. Pittock, 'Treacherous Objects: Towards a Theory of Jacobite Material Culture', Journal for Eighteenth-Century Studies 34: 1 (2011), 39-63.

72. Navickas, 'Spirit of Loyalty', p. 58.

73. Z. Dyndor, 'Wives, Widows and Witnesses: Women and their Involvement in the 1768 Northampton Borough Election', Parliamentary History 30: 3 (2011), 309-323.

74. Gleadle, Borderline Citizens, p. 187.

75. M. Roberts, Political Movements in Urban England, 1832-1914 (Palgrave: Basingstoke, 2008).

76. K. Harvey, reviewing McCormack, Independent Man at http://www.history. ac.uk/reviews/review/530. Accessed 10 December 2010.

77. Gleadle, Borderline Citizens; French and Rothery, Man's Estate.

78. S. Moore, “"A Nation of Harlequins”? Politics and masculinity in mid-eighteenth-century England', Journal of British Studies 49: 3 (2010), 514-539.

79. R. Clayton Windscheffel, 'Politics, portraiture and power: reassessing the public image of William Ewart Gladstone', in McCormack (ed.), Public Men, pp. 93-122.

Open Access This chapter is licensed under the terms of the Creative Commons Attribution 4.0 International License (http://creativecommons.org/licenses/ by/4.0/), which permits use, sharing, adaptation, distribution and reproduction in any medium or format, as long as you give appropriate credit to the original author(s) and the source, provide a link to the Creative Commons license and indicate if changes were made.

The images or other third party material in this chapter are included in the chapter's Creative Commons license, unless indicated otherwise in a credit line to the material. If material is not included in the chapter's Creative Commons license and your intended use is not permitted by statutory regulation or exceeds the permitted use, you will need to obtain permission directly from the copyright holder.

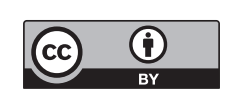

